\title{
Nadir Bir Olgu Sunumu: Kronik Böbrek Yetmezlikli Hastada İzole Çekal Nekroz
}

\section{A Rare Case Report: Isolated Cecal Necrosis in a Patient with Chronic Renal Failure}

\author{
Burak UÇANER, Muharrem ÖZTAŞ, Çağdaş KARAMAN, Baki TÜRKOĞLU, Şebnem ÇIMEN
}

Gülhane Eğitim ve Araştırma Hastanesi, Genel Cerrahi Kliniği, Ankara

\begin{abstract}
$\ddot{\mathbf{O z}}$
İzole çekal nekroz, iskemik kolite neden olan nadir bir durumdur. İskemik kolit ise oklüzifmezenterikiskemi ve oklüzif olmayan mezenterikiskemi olarak iki grupta değerlendirilir. Oklüzif olmayan akut kolonikiskemi düşük kan akımı nedeniyle çoğunlukla ileri yaș hastalarda gözlenmektedir. İzole çekal nekroz; kronik böbrek yetmezliği, kronik kalp hastalıkları, sistemik enfeksiyonlar ve diyabetesmellitus gibi sistemik hastalığı olan popülasyonda daha sık görülmektedir. İzole çekal nekroz tedavisinde sağ hemikolektomi ve ileotransverostomi genel olarak tercih edilen cerrahi teknik olmasının yanında farklı tedavi modaliteleri de mevcuttur. Bu olguda kronik böbrek yetmezliği olan, akut batın nedeniyle ameliyat edilen ve intraoperatif olarak izole çekal nekroz tanısı konulan 54 yaşında kadın hasta ve literatür bilgileri sunulmaktadır.

Anahtar Kelimeler: İzole Çekal Nekroz, Kronik Böbrek Yetmezliği, Oklüzif Olmayan Mezenterik İskemi
\end{abstract}

\section{Giriş}

İzole çekal nekroz, birçok nedene bağlı olarak ortaya çıkabilmektedir ve iskemik kolitin nadir gözlenen bir nedenidir. Oklüzif olmayan izole çekal nekroz; kronik böbrek yetmezliği, kronik kalp hastalığ ileri yaş hastalarda, düşük kan akımına bağlı olarak daha çok gözlenmektedir $(1,2)$. İzole çekal nekrozun çekal arterlerin ateroembolik veya tromboembolik oklüzyonuna sekonder geliştiği bildirilmiştir $(3,4)$. Akut batın nedenlerinden biri olan izole çekal nekroz genellikle sağ alt kadran ağrısı ile karşımıza çıkar ve akut apandisiti taklit edebilir. Nadir akut batın nedenlerinden biri olarak karşımıza çıkabilen ve sağ alt kadran ağrılarında ayırıcı tanıda gözden kaçmaması gereken izole çekal nekroz olgumuzu paylaşmayı amaçladık.

\section{Olgu}

Elli dört yaşında kadın hasta 3 gündür sağ alt kadranda ağrı, bulantı-kusma, gaz ve gaita

\begin{tabular}{lc}
\hline & ORCID No \\
Burak UÇANER & $0000-0002-5420-3810$ \\
Muharrem ÖZTAŞ & $0000-0001-6819-6511$ \\
Çăgdaş KARAMAN & $0000-0002-6832-498 X$ \\
Baki TÜRKOĞLU & $0000-0002-5777-7545$ \\
Şebnem ÇİMEN & $0000-0001-8344-3509$ \\
Başvuru Tarihi / Received: & 15.10 .2020 \\
Kabul Tarihi / Accepted : & 14.09 .2021 \\
Adres / Correspondence : & Burak UÇANER \\
Gülhane Eğitim ve Araştırma & Hastanesi, Genel Cerrahi Kliniği, \\
Ankara & \\
e-posta / e-mail & burakucaner@hotmail.com \\
\hline
\end{tabular}

\begin{abstract}
Isolated cecal necrosis is a rare condition that causes ischemic colitis. Ischemic colitis is evaluated in two groups as occlusive mesenteric ischemia and non-occlusive mesenteric ischemia. Nonocclusive acute colonic ischemia is mostly observed in elderly patients due to low blood flow. Isolated cecal necrosis; chronic kidney failure, chronic heart diseases, systemic infections and diabetes mellitus are more common in the population with systemic disease. In the treatment of isolated cecal necrosis, right hemicolectomy and ileotransverostomy are generally preferred surgical techniques, as well as different treatment modalities. In this case, a 54-year-old female patient with chronic renal failure, operated for acute abdomen, and diagnosed as isolated cecal necrosis is presented and literature information is presented.

Keywords: Chronic Kidney Failure, Isolated Cecal Necrosis, Nonocclusive Mesenteric Ischemia
\end{abstract}

çıkaramama ve iştahsızlık şikayetleri ile başvurdu. Hastaya yapilan fizik muayenede sağ ve sol alt kadranlarda rebound bulgusu pozitif olarak değerlendirildi, yapılan rektal muayenede ampulla boştu. Diğer sistem muayeneleri normal olarak saptandı. Hastanın özgeçmişinde 2005 yılında geçirdiği apendektomi ve 2009 yılında geçirdiği sol nefrektomi ameliyatları mevcuttu. Hasta kronik böbrek yetmezliği nedeniyle hemodiyaliz tedavisi görmekte. Hastaya yapılan laboratuvar tetkiklerinde beyaz küre sayıs1: 15100 cells/Ul, CRP: 309 mg/L, Üre: 60 mg/dl, Kreatinin: $4.49 \mathrm{mg} / \mathrm{dl}$ olarak saptandı, diğer biyokimyasal parametreleri normal değerlerdeydi. Hastaya çekilen ayakta direkt batın grafisinde hava siv1 seviyeleri mevcuttu. Ayrica hastaya çekilen tüm abdominal bilgisayarlı tomografide periçekal alanda heterojenite (Resim 1) ve lümen içerisinde gaz odakları (Resim 2) mevcuttu. Hastaya acil şartlarda tanısal laparaskopi yapılmas1 planlandi. Yapilan eksplorasyonda çekumun yaklaşık 15 cm'lik kısmını ilgilendiren nekrotik alan gözlendi ve laparatomi yapılmasına karar verildi. Göbek üstü ve göbek altı orta hat kesi yapılarak batına girildi. Hastaya ileoçekal rezeksiyon yapıldı. Daha sonra ileum ve asendan kolon arasında yan yana ileokolik anastomoz gerçekleştirildi. Hastaya intraoperatif dönemde 1. Kuşak sefalosporin ve metronidazol uyguland. Postoperatif dönemde ise enfeksiyon hastalıkları kliniğinin önerileri doğrultusunda piperasilintazobaktam ve metronidazol uyguland. Hastanın postoperatif takiplerinde komplikasyon 
gelişmedi ve hasta postoperatif 8 . günde taburcu edildi.

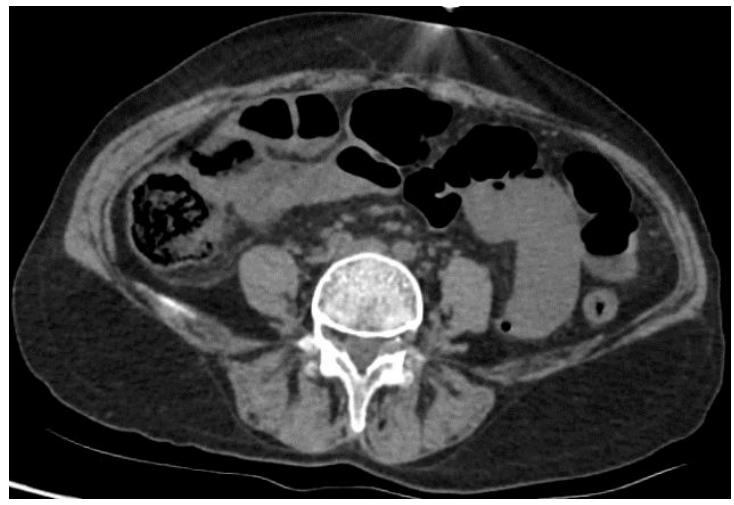

Resim 1. Tüm abdominal bilgisayarlı tomografide periçekal alanda heterojenite

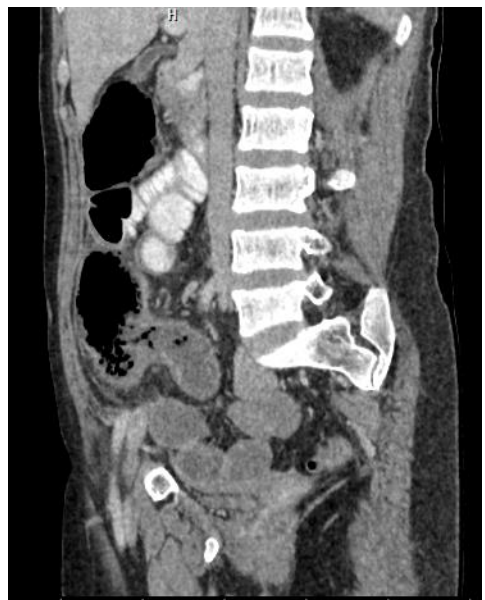

Resim 2. Bilgisayarlı tomografide lümen içerisinde gaz odakları

\section{Tartıșma}

İskemik kolit kolon kan akımında azalmaya bağlı olarak görülmektedir. Nadir kolonik iskemi nedenlerinden biri olan izole çekal nekroz akut batının ayırıcı tanısında önem arz etmektedir. İzole çekal nekroz fizik muayene bulguları itibari ile akut apandisiti taklit edebilir $(5,9)$. Kolon iskemisi için spesifik bir serum belirteci bulunmamaktadır. Tanıda kullanılan görüntüleme yöntemleri arasında abdominal ultrasonografi ve abdomene yönelik bilgisayarlı tomografi bazı olgularda faydalı olmaktadır. Kolon duvarında kalınlık artışı olması ve lümen içerisinde hava imajları gözlenmesi kolonik iskemiyi akla getirebilmektedir (4). İskemik kolit şüphesi olan hastalarda tanıda kolonoskopinin kullanımı tartışma konusudur. Kolon perforasyonu riskini artırabileceğinden dikkatli olunmalıdır. Tanıda ayrıca tanısal laparoskopi de bir seçenektir (6). İzole çekal nekroz; kronik böbrek yetmezliği, kronik kalp hastalıkları, sistemik enfeksiyonlar ve diyabetes mellitus gibi sistemik hastalığı olan popülasyonda daha sik görülmektedir (7). Hemodiyaliz hastaları izole çekal nekroz gelişimine daha yatkın hastalardır $(8,9)$. Sağ alt kadran ağrısı durumunda, özellikle hemodiyaliz hastalarında, diyabetli yaşlı hastalarda ve kronik kalp hastalığında izole çekal nekroz olasılığı akılda tutulmalıdır; cerrahi stratejiler buna göre planlanmalı ve tanıda gecikme olması durumunda mortalitenin yüksek olacağı bilinmelidir.

Hasta Onamı: Hasta onamı 08.01.2020 tarihinde alınmıştır.

\section{Kaynaklar}

1. Gundes E, Kucukkartallar T, Colak MH, Cakir M, Aksoy F. Ischemic Necrosis of the Cecum: A Single Center Experien $\neg$ ce. Korean J Gastroenterol. 2013;61:265-9 .

2. Yener O, Buldanlı MZ, Ekinci Ö, Tombalak E. Partial caecal necrosis, Hellenic J Surg. 2016;88(1):69-71.

3. Chan T, Levine MS, Park Y. Cholesterol embolization as a cause of ceca linfarct mimicking carcinoma. AJR Am J Roentgenol. 1998;150:1315-6.

4. Simon AM, Birnbaum BA, Jacobs JE. Isolated infarction of the cecum: CT findings in two patients. Radiology. 2000; 214:513-6.

5. Özcan Ö, Ersöz F, Dönmez M, Sentatar E, Bektas H, Sarı S, Arıkan S. Hemodiyalize bağımlı hastalarda izole çekum nekrozu: üç olgu sunumu. Kolon Rektum Hast Derg. 2011;21:120-5.

6. Çakar E, Ersöz F, Bag M ve ark. Isolated cecal necrosis: our surgical experience and a review of the literature. Ulusal Cer Derg. 2014;30:214-8.

7. Ori Y, Chagnac A, Schwartz A, et al. Non-occlusive mesenteric ischemia in chronically dialyzed patients: A disease with multiple risk factors. Nephron Clin Pract. 2005;101:87-93.

8. Beck DE, de Aguilar-Nascimento JE. Surgical management and outcome in acute ischemic colitis. Ochsner J. 2011;11:282-5.

9. Dirican A, Unal B, Bassulu N, Tatlı F, Aydin C, Kayaalp C. Isolated cecal necrosis mimicking acute appendicitis: a case series. J Med Case Reports. 2009;19:7443. 